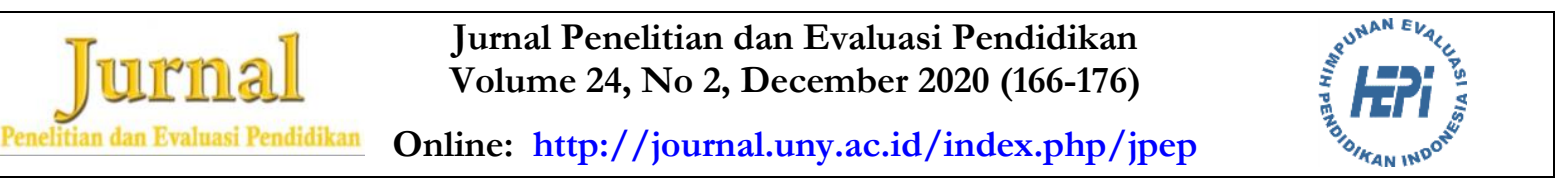

\title{
PROJECTION OF THE NUMBER OF STUDENTS AND THEIR ACCEPTANCE AT VARIOUS EDUCATIONAL LEVELS UNTIL 2025
}

\author{
Gayuh Nugroho Dwi Putranto ${ }^{1 *}$, Juliadi Nugroho ${ }^{1}$, Muhammad Zid ${ }^{1}$, Cahyadi \\ Setiawan ${ }^{1}$ \\ ${ }^{1}$ Department of Environmental Management, Universitas Negeri Jakarta \\ Jl. Rawamangun Muka, Rawamangun, Pulo Gadung, Kota Jakarta Timur, Jakarta 13220, Indonesia \\ *Corresponding Author. E-mail: nugrohogayuh31@gmail.com
}

\begin{abstract}
The 1945 Constitution states that education is a right for every citizen. Education is a conscious and planned effort to realize the atmosphere of learning and the learning process so that students can develop their potential. Education in Indonesia aims to educate the nation's life. Indonesia's education system in its development continues to make changes. The zoning policy in education is one form of positive response from the government to equalize education in each region. The zoning policy requires each student to go to school the closest distance from their residence. Schools provide about $90 \%$ of the student capacity measured by distance. The zoning policy in its development still leaves various problems. A common problem is the unavailability of educational facilities in a sub-district area so that some students have the potential to not go to school. Bekasi City is a metropolitan city that serves as a buffer for the capital city. In its development, Bekasi City has the potential to experience problems of inequality in the number of students and absorption in schools. This study aims to project the number of students and their absorption at various levels of education in Bekasi until 2025.
\end{abstract}

Keywords: projection, student acceptance, educational levels

How to cite: Putranto, G., Nugroho, J., Zid, M., \& Setiawan, C. (2020). Projection of the number of students and their acceptance at various educational levels until 2025. Jurnal Penelitian dan Evaluasi Pendidikan, 24(2), 166-176. doi:https:// doi.org/10.21831/pep.v24i2.33026

\section{INTRODUCTION}

Universal Declaration of Human Right by the United Nation (2005) is equal rights for every citizen. Equal education rights can be found in Article 26 paragraphs 1 and 2. The article explains the equality in education for every citizen, and requires education to citizens. Another guarantee related to the right to education is the International Covenant on economic, social and cultural rights. Article 13 of the Constitution Regarding the Ratification of the International Covenant on Economic, Social, and Cultural Right (2005) concerning Ratification of the International Coevenant on Economic, Social and Cultural Right recognizes that education is the right of every citizen. Education in Indonesia is written in Constitution Regarding the Rights and Obligations of Indonesian Citizens (1945) in article 28 paragraph 1 which states:

...every citizen has the right to develop themselves through the fulfillment of their basic needs, the right to get education and benefit from science and technology, arts and culture, in order to improve their quality of life and for the welfare mankind.

The statement is in accordance with the objectives of the state contained in the opening of the 1945 Constitution, which is to educate the nation's life. In its implementation, education can be done fairly and evenly through an educational approach inside and outside the school. 
167 - Gayuh Nugroho Dwi Putranto, Juliadi Nugroho, Muhammad Zid, \& Cahyadi Setiawan

doi doi:https://doi.org/10.21831/pep.v24i2.33026

Indonesia has arranged all forms of national education activities in detail in Law No. 3 of 2003. Systematically the education system regulated in Constitution Regarding National Education System (2003) is an integrated whole education component to achieve national education goals. Some research explain that the development of Indonesian education is transforming from the era of the industrial revolution 4.0 to social education 5.0, which implies the application of education in a democratic and fair manner (Adha et al., 2019; Nastiti \& Abdu, 2020; Parker \& Raihani, 2011). In the education process there are educational components that can form patterns of interaction or influence one another. Components are part of a system that has a role for the continuity of the process and achieve system goals. Based on the results of the study, there are several components in the education system, one of which is the environment. The environment influences the potential and ability of a student. This environment can be internal and external factors. Internal factors are factors that originate from individuals, while external actors are factors that come from outside the individual. School is one of the external factors that influence the ongoing education process (Coombs, 1968; Indriyani, 2014). The school is one of the educational institutions that intentionally, directed and systematically creates the widest opportunity for self-development. Based on the results of previous studies it is said that there is a relationship between variations in distance to school on student learning achievement. The existence of a school that is close to where students live will affect student achievement. In another study explained that $70.8 \%$ of student learning achievement is influenced by academic support and distance of student residence. This explains the existence of schools close to where they live will have a positive impact on student achievement (Lestari et al., 2015; Surani, 2012).

Regulation of the Minister of Education and Culture No. 14 regarding the Student Admission (2018) regulates the zoning system which prioritizes distance as the main requirement for student admission. The implementation of this policy has several negative impacts. Based on the results of the study, lack of socialization, school inequality, over capacity, the small amount of the quota for the percentage of students who excel is a problem that often arises in this policy (Nurlailiyah, 2019; Perdana, 2019; Wahyuni, 2019).

Bekasi is a metropolitan city that acts as a buffer zone for the capital city. Bekasi is also an urbanization area that becomes a destination for rural communities. Urbanization itself in environmental science is defined as the urbanization of a region. Harahap (2013) believes that this urbanization is defined as two processes, the first is an essentially political change defined as socio-economic transformation arising from the development and expansion of capitalism, the second is the change in value from traditional orientation to modern orientation. Therefore, it can be said that the definition of urbanization is the process of changing from rural to urban society which includes its territory and the people in it and is influenced by physical or morphological, social, economic, cultural and psychological aspects of the community.

Urbanization become factors that impede the management of the city. Increasing the process of urbanization is inseparable from the policy of urban spatial planning. Changes in an urban spatial characteristic of modernity that affect every citizen, and the presence of investors or developers is a form of investment that is related to the demands of the global economy. From a spatial perspective, the phenomena of contestation, negotiation, consensus and conflict are understood as a form of power relations of spatial actors, namely government, community, and investors. The relation of these three factors influences spatial practice (Aminah, 2016; Harahap, 2013; Lefebvre, 1991).

The Bekasi City government in its role as the owner of land and the highest policy maker in determining the Regional Spatial Planning and Spatial Detailed Plan in Bekasi must be able to be neutral. The zoning policy in education will change part of Bekasi's urban spatial layout. One of the President Joko Widodo's nine priorities for the next five years (nawacita) is a 12 -year compulsory education, but this is still constrained by legality and legal protection in 
the form of laws and regulations. Education is a right for every citizen guaranteed by article 31 of Constitution on Education (1945). This is the basic foundation that the availability and accessibility of education must be fulfilled by the state without exception. The 12-year compulsory education program emphasizes that Elementary School-High School education is a right for the community including the ease of achieving it.

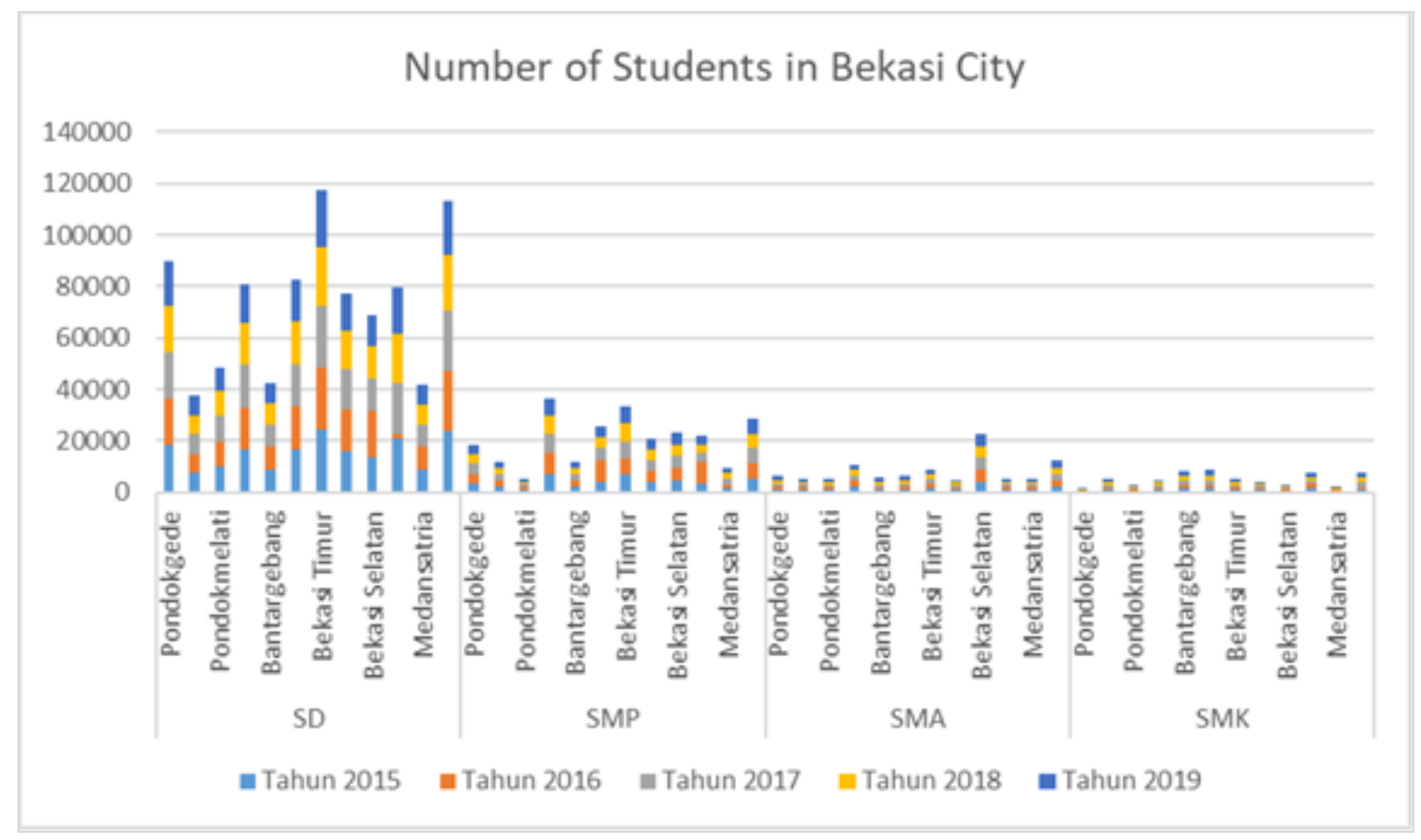

Figure 1. Number of Students of Each Level in Bekasi City for the Period of 2015-2019

Data in Figure 1 illustrate a gradually increase in the number of students in the period 2015-2019 in Bekasi City at all levels of education. Its capacity and absorption in schools is a potential problem for future data for the people of Bekasi City. Thus, this study aims to project the number of students and their absorption at various levels of education in the city of Bekasi until 2025. This research is expected as an alternative to anticipating the shortage of the capacity of elementary school students, junior high school students, senior high school students and vocational school students in the city of Bekasi in 2021 based on the results of planning modeling by comparing the capacity and number of students.

\section{RESEARCH METHOD}

This study uses a quantitative descriptive approach to explain the problems in this study. Data were collected from the secondary time series data obtained from Central Bureau of Statistics of Bekasi City, in the form of the number of school students (elementary, junior high, high school and vocational school). The data were performed using forecasting model with the moving average method. Subagyo (2009) explained that moving average is a method of forecasting which is done by taking a group of average data values as a future prediction. Hyndman and Athanasopoulos (2018) explain that to do accurate forecasting using a moving average requires historical data for a certain period of time. The data capacity was in the form of secondary data and considered to be permanent until 2025. These data were then compared and interpreted and analyzed based on literature review and other scientific articles. The data were then discussed by considering the school distribution as presented in Figure 2. 


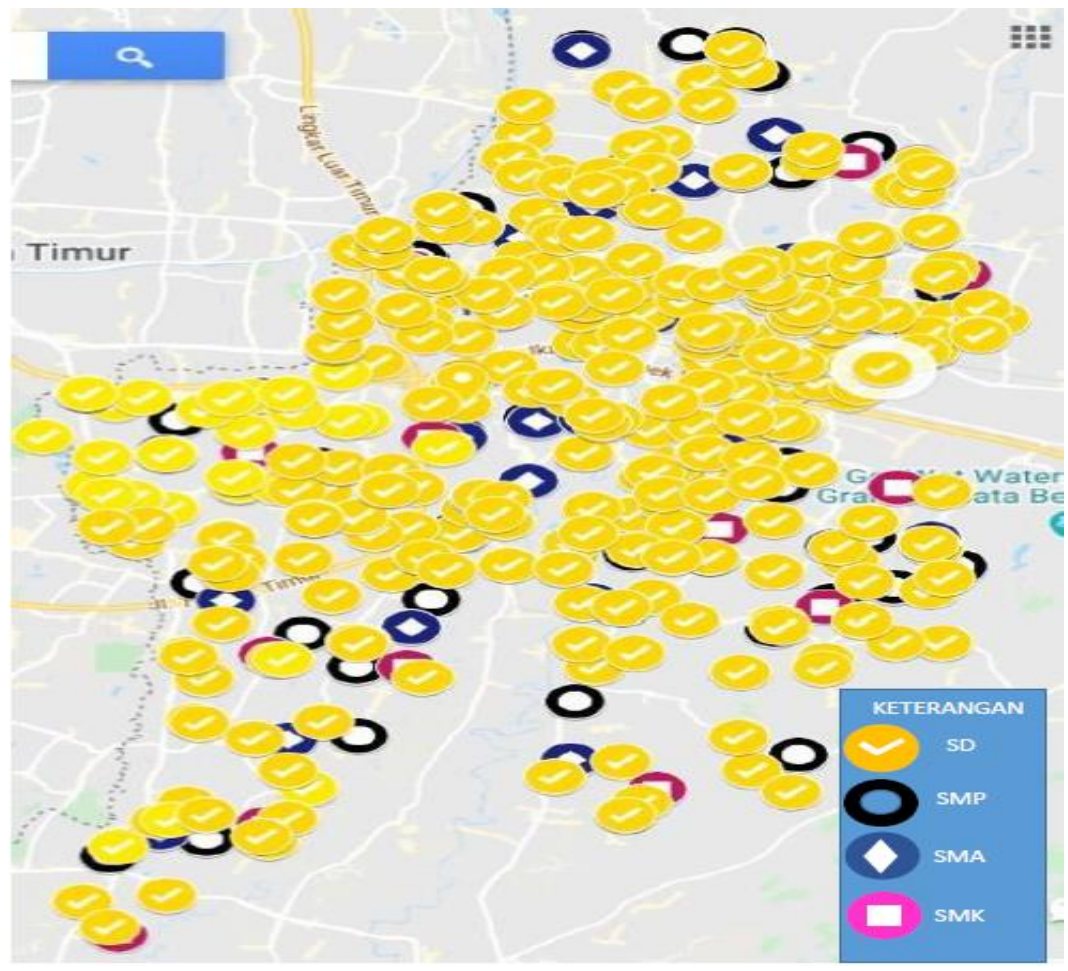

Figure 2. Distribution of Schools in Bekasi City

\section{FINDINGS AND DISCUSSION}

The results of calculation of student project data in each district in Bekasi city are presented in Figure 3 and Figure 4. Based on the calculation of the projection of the number of students in Bekasi City, the elementary school levels decreased by 2025.

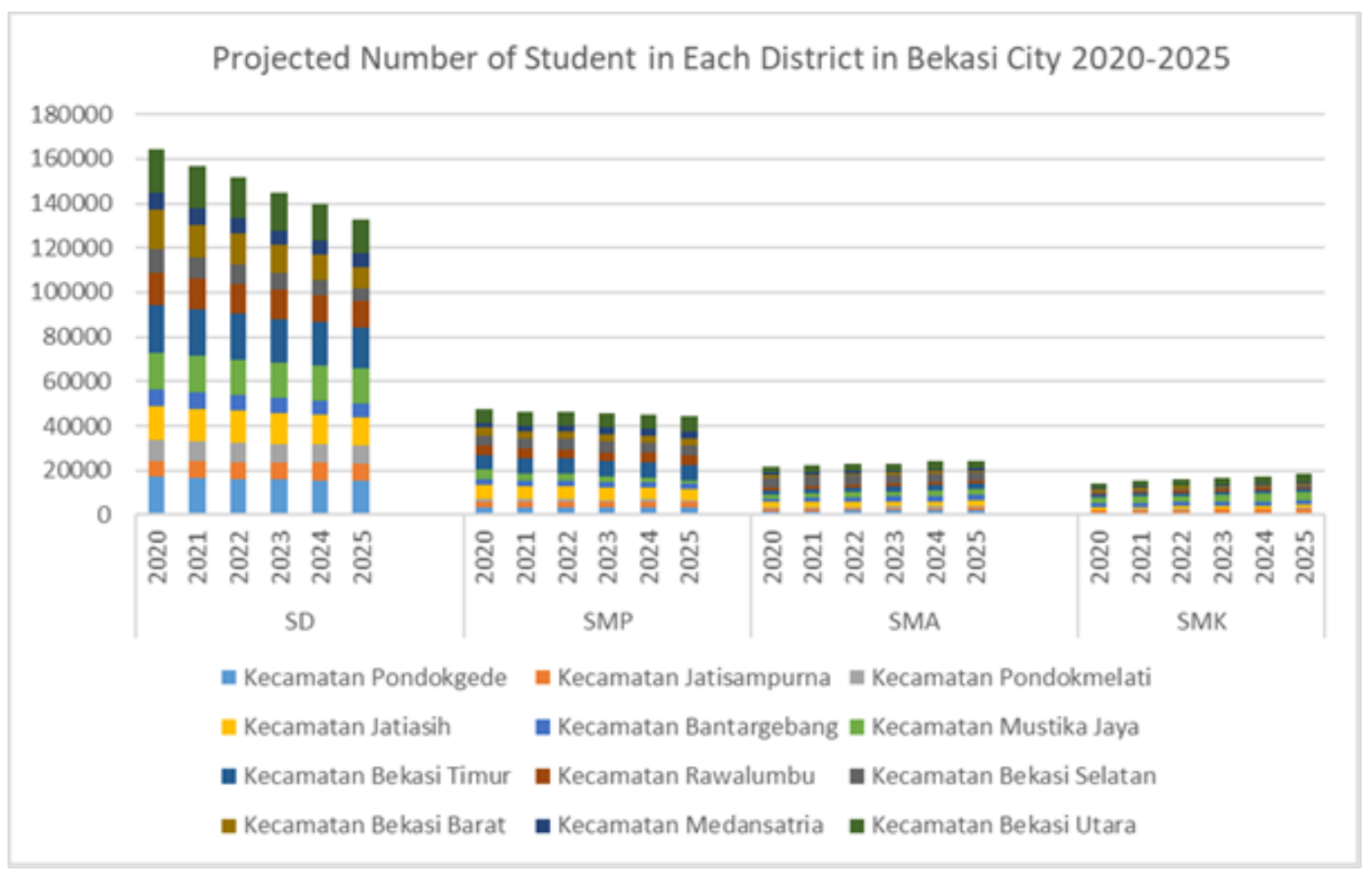

Figure 3. Projected Number of Students in Each District in Bekasi City

Copyright (C) 2020, Jurnal Penelitian dan Evaluasi Pendidikan, 24(2), 2020

ISSN (print) 2685-7111 | ISSN (online) 2338-6061 
170 - Gayuh Nugroho Dwi Putranto, Juliadi Nugroho, Muhammad Zid, \& Cahyadi Setiawan

doi doi:https://doi.org/10.21831/pep.v24i2.33026

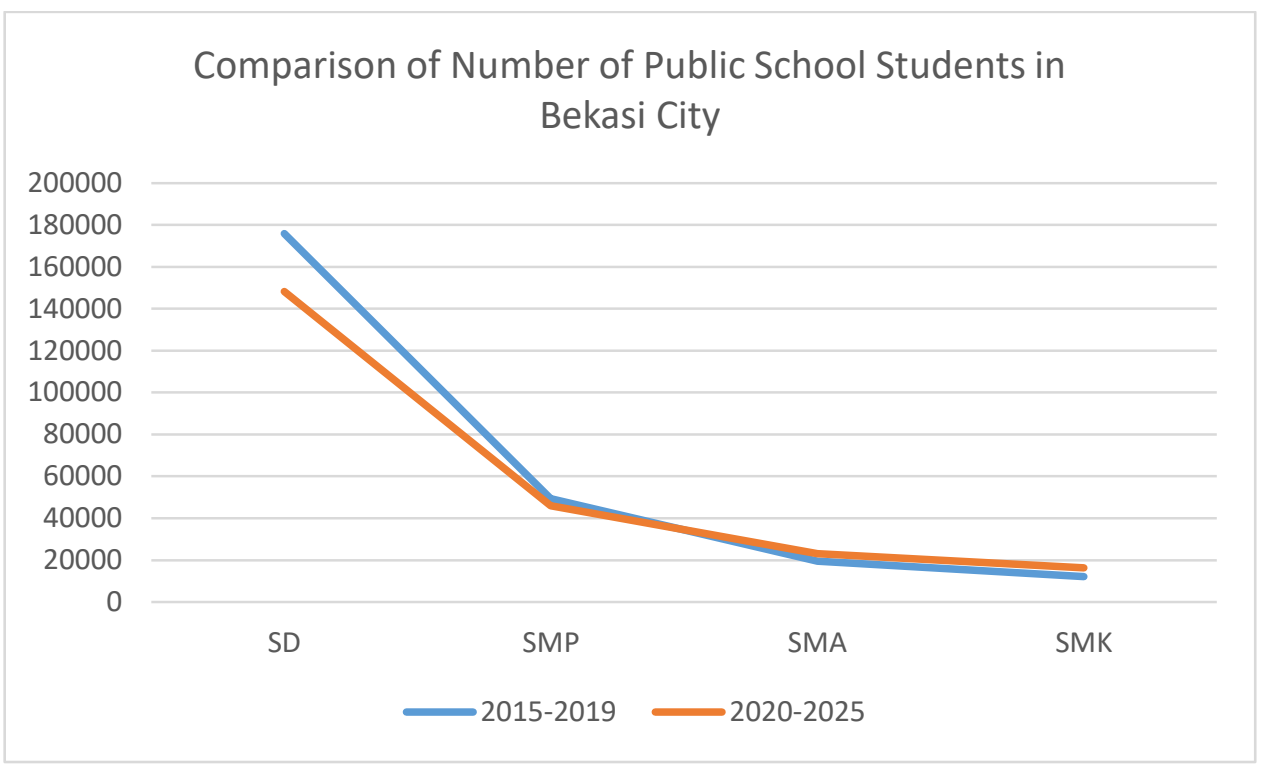

Figure 4. Comparison of Number of Public School Students in Bekasi City

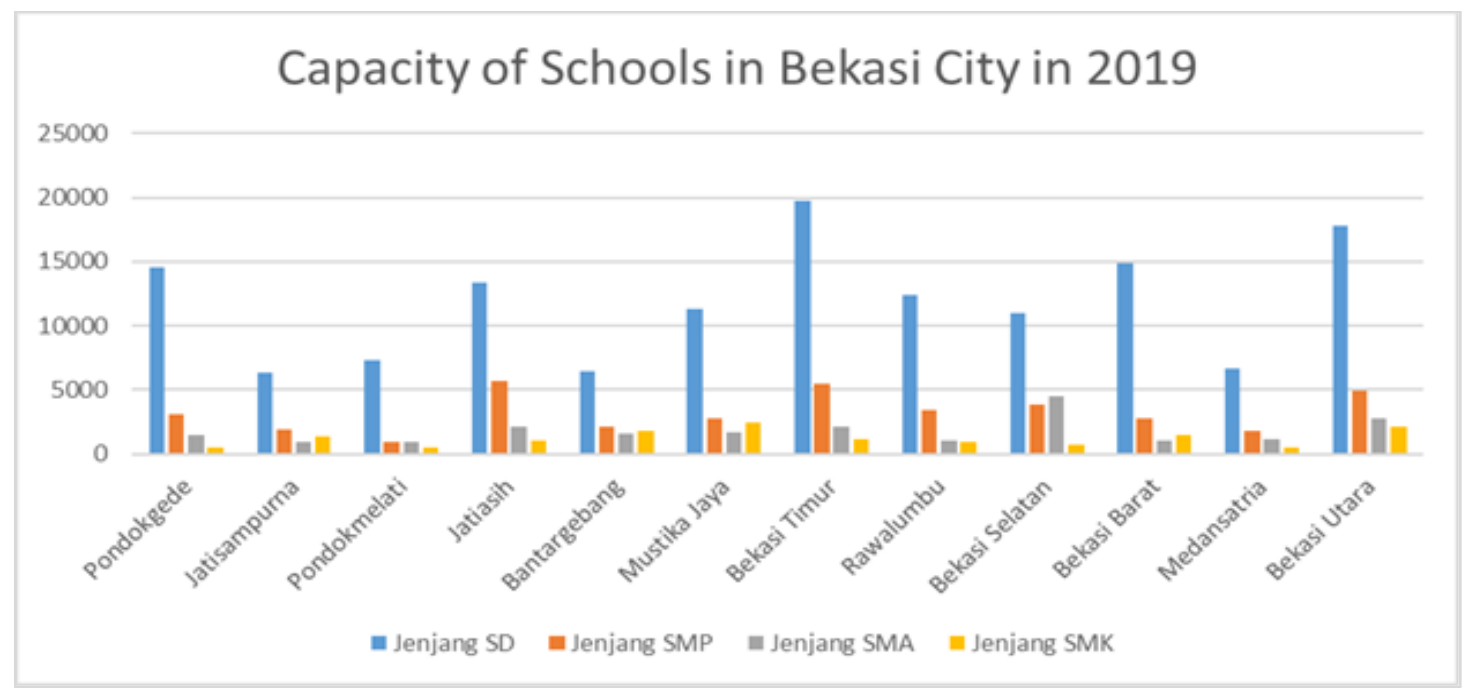

Figure 5. Capacity of Schools of Various Levels in Bekasi City

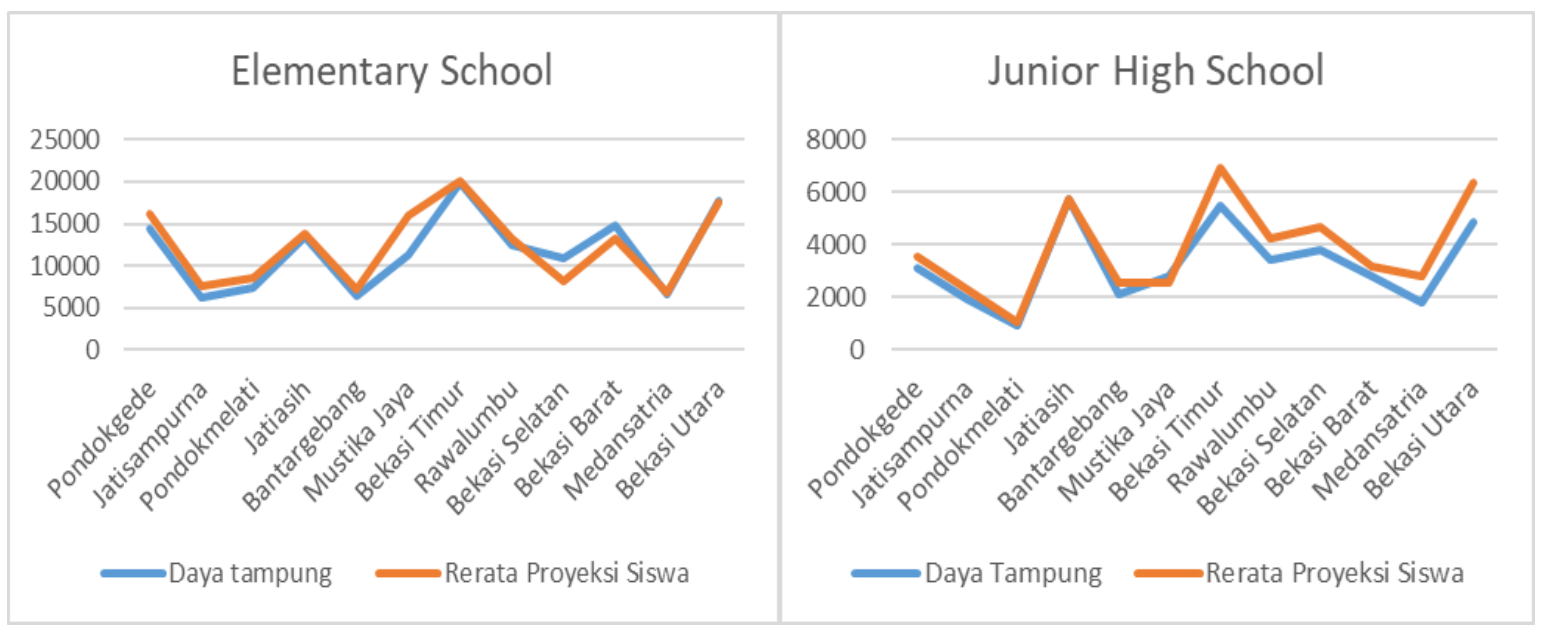

Figure 6. Comparison of Projection of the Number of 2020-2025 Students with Capacity in Elementary and Junior High Schools

Copyright (C) 2020, Jurnal Penelitian dan Evaluasi Pendidikan, 24(2), 2020

ISSN (print) 2685-7111 | ISSN (online) 2338-6061 
171 - Gayuh Nugroho Dwi Putranto, Juliadi Nugroho, Muhammad Zid, \& Cahyadi Setiawan

doi doi:https://doi.org/10.21831/pep.v24i2.33026

Based on Figure 4, Junior High School levels tend to be stable for the number of students up to 2025. Senior High school and vocational school based on data is projected to increase in number by 2025 . The number of student projections must be balanced with the availability of capacity and absorption in the school. The capacity in this study is considered stable. Therefore, using data in 2019, the school capacity in Bekasi is presented in Figure 5 and Figure 6.

Based on these projections, it is known that Mustikajaya district has the potential to experience over capacity with the highest number of students until 2025. The excess number of students is shown in the graph in the form of a gap between the capacity and the average student projection for 2020-2025. Geographically, Mustika jaya District has 23 state elementary schools. The high gap in the number of students and capacity leads to high competition of elementary school student candidates in the district. The number of students is inversely proportional to the projected number of students in South Bekasi. Figure 6 shows that South Bekasi district is a district with a projection of the lowest number of students until 2025. This shows that until 2025 it is predicted that the area will experience a shortage of elementary students. The data illustrates that the distribution of school facilities is still an obstacle in the implementation of the zoning system, especially at the elementary level. Medcom (2019) explains that the number of graduates for elementary schools in Bekasi City are 43,000 students, while the available capacity is only 14,000. Instead, Kendari City zoning system caused three elementary schools from 13 Elementary School in Kelurahan Kampung Sulo, Kendari District to be merged into one elementary school. This merger caused a lack of students at the elementary school (Hendrik, 2019).

Excess students for junior high school levels occur in East Bekasi District. At the junior high school level, the Bekasi Timur District is projected to have the most potential to experience overcapacity of students until 2025. At the junior high school level, East Bekasi district has a significant increase in the number of students compared to other districts. Over Capacity of students in an area also signifies a quite high competition to enter the state senior high school (sekolah menengah pertama negeri or SMPN) in the district. This is based on zoning regulations that prioritize distance over achievement. East Bekasi District is geographically a district where there is SMPN 1 Bekasi. Excess students at the junior high school level in East Bekasi district will potentially close the achievement path for students in other districts to enter SMPN 1 Bekasi City. The potential of violations will be created if school equity is not met. According to Hidayat and Rachmani (2019) at Ombudsman.id news, violations were found in the form of the intervention of regional officials in East Java and Bali as well as the prospective students who falsified the Family Card and the possibility of domicile. This is in line with the statement of the Governor of Central Java, Ganjar Pranowo, in a press release, saying that "Many found students enter favorite schools using fake domisis letters" (Nursanti, 2020). The projection data for junior high school students until 2025 as presented in Figure 6 also shows that Mustika Jaya District has the potential to experience a shortage of students for junior high school level. Central Bureau of Statistics (2020) data explains the number of public junior high schools in Mustika Jaya District is five units. The number is inversely proportional to the region which has the highest number of students only having 1 state junior high school. Geographically and administratively Mustika Jaya Subdistrict is a sub-district which borders directly with East Bekasi Subdistrict. Transferring the number of students in the nearest district can be an alternative solution if the equal distribution of capacity is difficult for Bekasi City Government.

Based on Figure 7, it is known that Bantargebang and Mustikajaya Districts have a high potential to overcapacity up to 2025 . Medansatria District based on these data; it is known that the capacity is still sufficient until 2025. In terms of the vocational school level, as explained in Figure 7, Mustikajaya District has a high potential to overcapacity the number of students until 
172 - Gayuh Nugroho Dwi Putranto, Juliadi Nugroho, Muhammad Zid, \& Cahyadi Setiawan

doi doi:https://doi.org/10.21831/pep.v24i2.33026

2025. West Bekasi District becomes a district that has the potential to experience shortages based on student projection data. This is due to differences in interest in junior high school students continuing their vocational and high school education. Based on Figure 7, it can be explained at the high school level in the Districts of Bantar Gebang and Mustika Jaya that are experiencing overcapacity while at the Vocational School level experiencing shortages. Based on Tempo 2019's report, the reason for the lack of applicants for Public Vocational High School 14 Bekasi City was that it was located far from densely populated settlements. The zoning policy causes the distance of public vocational high school 14 Bekasi to tend to be closer to Depok City, causing the number of public vocational high school registrants to only 25 people. Based on the results of the study, other influential factors are the lack of facilities and infrastructure, the absorption of vocational graduates in the world of work (Dharmayanti \& Munadi, 2014; Sayidani et al., 2016; Windarto, 2013).

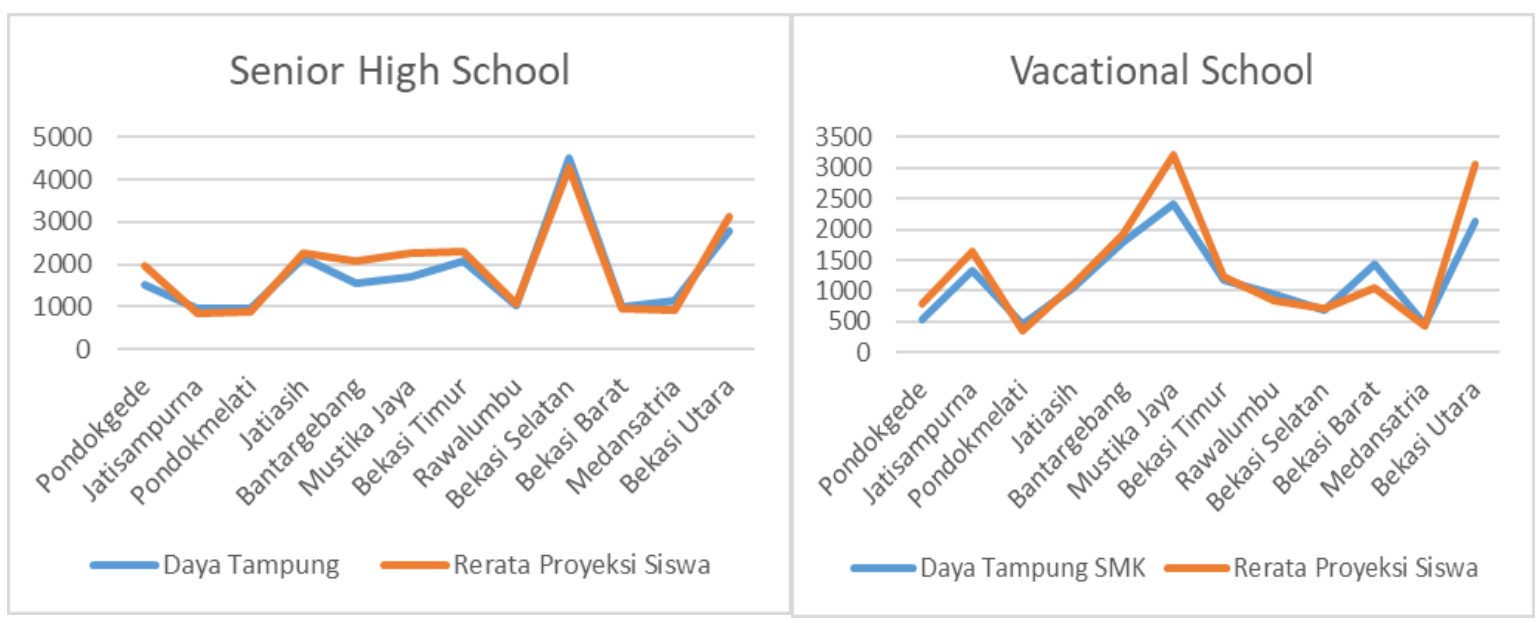

Figure 7. Comparison of Projection of 2020-2025 Students with High School and Vocational High Capacity

The problems are that the majority of private schools are homogeneous and based on shared beliefs, for example, the Islamic school, the Catholic School (Bachrie, 2009). This raises the community's perception that religious equality underlies the reasons parents send their children to these private schools. This of course will be a problem in Indonesia which is a country with various religions and beliefs. Private schools are schools that are managed independently so that there is no limit to the quota of students for each academic year. This has led to a shift in the purpose where private schools tend to accommodate as many students as possible by reducing their passing grades. Istanto (2014) explained that the problem generally faced by private schools in the formulation of strategies in school management due to the lack of government presence in it. The government is more focused on public schools in determining criteria both in quality and quantity

Public perception regarding public vocational high school is still low. Based on several research results, it is clear that the public is still worried about putting their children in vocational schools due to the lack of competent graduates and the poor organization of vocational schools themselves (Fitasari, 2017; Salsabila, 2018). This inequality has the potential to cause problems in implementation in Bekasi City.

Private schools are becoming an alternative amid the minimal number of educational facilities due to an excessive number of students. This alternative is considered unable to solve the zoning problem. Cost considerations become a determining factor for parents of students to send their children to private institutions. The cost of education is one component of instrumental input that is very important in the administration of education. Article 12 of Con- 
173 - Gayuh Nugroho Dwi Putranto, Juliadi Nugroho, Muhammad Zid, \& Cahyadi Setiawan

doi doi:https://doi.org/10.21831/pep.v24i2.33026

stitution Regarding National Education System (2003) states that every student is obliged to share in the costs of providing education. Private schools are required to finance their implementation privately, this causes high costs to be expended so that it becomes a problem for students (Sanjiwani, 2012).

Other problems that arise are different competitions in each district in the city of Bekasi. Overcapacity in Mustikajaya District causes a higher level of competition to be able to go to school. Some districts with a high number of students will create a different competition when compared to districts with a minimum number of students. Based on the data, there is a striking difference between the competition that occurred in Bantargebang and Jatisampurna Districts in terms of admission of high school students. The data predict that in 2021, Bantargebang sub-district will have a deficit of around 21\%, while Jatisampurna sub-district is predicted to be over capacity by $2 \%$ based on the total number of students in 2021 . Wahyuni (2019) explained that the zoning system would eliminate the perception of superior schools. The perception of superior schools arises because schools have advantages compared to other schools such as learning systems, quality of competent teachers, etc. This causes students to not be able to attend the high school that they want. Azanella (2019) reported that this zoning policy caused a decline in the quality of education. Students with high grades cannot attend excellent schools because the superior schools are far from where they live. This causes contra-productive between the main objectives of the zoning policy with the distribution of education with an increase in academic quality. Thaib (2013) explains that motivation is a driving force of behavior that arises because of a desire in a person. If students are forced to study in a school that is not their choice, then, according to some theories explained, their motivation to achieve and learn to be low.

These problems have the potential to arise if there is no improvement in the zoning system. The need for educational facilities in the form of elementary and junior high schools in the city of Bekasi is a real challenge that must be solved by the municipal government of Bekasi. This is certainly contrary to the goal of national education to develop students' potential. Bekasi City Government is demanded to be able to do space planning to meet the minimum level of education facilities for elementary and junior high schools in Bekasi City by adding classes or establishing new schools. Bekasi City Spatial Planning is a measure of the success of Bekasi City Government in accommodating public interests in the form of education and the ease of obtaining it. Levebre in Hendra (2018) explained that space is a very dynamic social product so that space can be produced socially by the three elements namely the government, capitalists, society. Bekasi City Government as the government that controls the space is expected to be able to bring spatial planning policies to fulfill the people's right to education.

\section{CONCLUSION}

Based on the research findings, it can be concluded as follows. (1) Acceptance of students based on the projected number of students up to 2025 has the potential to cause overcapacity at the elementary and junior high school levels in the majority of districts in Bekasi City. (2) The absorption of students based on projected data at the high school and vocational levels is caused by differences in public perception about the quality of high school and vocational school.

\section{REFERENCES}

Adha, M. A., Gordisona, S., Ulfatin, N., \& Supriyanto, A. (2019). Analisis komparasi sistem pendidikan Indonesia dan Finlandia. Tadbir: Jurnal Studi Manajemen Pendidikan, 3(2), 145. https://doi.org/10.29240/jsmp.v3i2.1102 
174 - Gayuh Nugroho Dwi Putranto, Juliadi Nugroho, Muhammad Zid, \& Cahyadi Setiawan

doi doi:https://doi.org/10.21831/pep.v24i2.33026

Aminah, S. (2016). Konflik dan kontestasi penataan ruang Kota Surabaya. MASYARAKAT: Jurnal Sosiologi, 20(1), 59-79. https://doi.org/10.7454/mjs.v20i1.4751

Azanella, L. A. (2019). Zonasi dinilai malah membuat mutu pendidikan rendah akan merata. Kompas. https://edukasi.kompas.com/read/2019/06/20/11465771/zonasi-dinilai-malahmembuat-mutu-pendidikan-rendah-akan-merata?page=all

Bachrie, N. S. (2009). Hubungan jenis sekolah dan identifikasi nilai moral individualisme terbadap kesadaran sosial siswa SMA di Jakarta [Bachelor's Thesis, Universitas Indonesia]. Digital Library UI. http://lib.ui.ac.id/file?file=digital/125939-371.9 NAM h - Hubungan jenis HA.pdf

Central Bureau of Statistics. (2020). Jumlah sekolah menengah pertama swasta di Kota Bekasi. https://bekasikota.bps.go.id/subject/12/kependudukan.html\#subjekViewTab3

Constitution on Education, Pub. L. No. 31 (1945).

Constitution regarding the Rights and Obligations of Indonesian Citizens, Pub. L. No. 28 (1945).

Constitution regarding national education system, Pub. L. No. 20 (2003).

Constitution regarding the Ratification of the International Covenant on Economic, Social, and Cultural Right, Pub. L. No. 11 (2005). https://jdih.kemnaker.go.id/data_puu/5.pdf

Coombs, P. H. (1968). The world educational crisis: A system analysis. Oxford University Press. https://doi.org/10.1080/00131726909339817

Dharmayanti, W., \& Munadi, S. (2014). Faktor-faktor yang memengaruhi minat siswa SMP masuk SMK di Kota Pontianak. Pendidikan Vokasi, 4(3), 405-419. https://doi.org/ $10.21831 /$ jpv.v4i3.2563

Fitasari, N. (2017). Persepsi warga sekolah tentang penerapan peraturan 5 hari kerja di SMKN 1 Cilacap Jawa Tengah [Bachelor's Thesis, Universitas Negeri Yogyakarta]. Eprints UNY. http://eprints.uny.ac.id/id/eprint/46395

Harahap, F. R. (2013). Dampak urbanisasi bagi perkembangan kota di Indonesia. Society, 1(1), 35-45. https://doi.org/10.33019/society.v1i1.40

Hendra, D. (2018). Analisis pemikiran Henri Levebvre tentang ruang dalam arsitektur modern: Suatu perspektif sosiologis. Jurnal Ilmiah Mimbar Demokrasi, 17(2), 178-189. https://doi.org/10.21009/jimd.v17i2.9092

Hendrik, B. (2019). Gara - gara sistem zonasi PPDB, dua SDN di Kendari dilebur jadi satu. Media Kendari. https://mediakendari.com/amp/gara-gara-sistem-zonasi-ppdb-dua-sdn-dikendari-dilebur-jadi-satu/49904/

Hidayat, M. A., \& Rachmani, A. P. (2019). Ombudsman temukan beberapa pelanggaran PPDB sistem zonasi sekolah. Viva. https://www.viva.co.id/berita/nasional/1169593-ombudsmantemukan-beberapa-pelanggaran-ppdb-sistem-zonasi-sekolah

Hyndman, R. J., \& Athanasopoulos, G. (2018). Forecasting: Principles and practice (2nd ed.). OText. https://otexts.com/fpp2/

Indriyani, R. (2014). Pengarub asal sekolah dan tempat tinggal terhadap prestasi belajar mahasiswa prodi D III Kebidanan Universitas Wiraraja Sumenep [Master's Thesis, Universitas Sebelas Maret]. Eprints UNS. http://eprints.uns.ac.id/20706/1/COVER.pdf

Istanto, A. (2014). Strategi peningkatan kualitas sekolah swasta (Studi kasus di SMP X Kab. Semarang). Journal of Education Policy, 1(2), 42-50. 
175 - Gayuh Nugroho Dwi Putranto, Juliadi Nugroho, Muhammad Zid, \& Cahyadi Setiawan

doi doi:https://doi.org/10.21831/pep.v24i2.33026

Lefebvre, H. (1991). The production of space (D. Nicholson-Smith (Trans.). Blackwell.

Lestari, S. A., Kusumo, H., \& Moro, E. P. (2015). Perbandingan variasi jarak tempuh ke sekolah terhadap prestasi belajar IPA siswa kelas VII SMP Muhammadiyah 2 Kalibawang. JURNAL BIOEDUKATIKA, 3(1), 33. https://doi.org/10.26555/ bioedukatika.v3i1.4145

Medcom. (2019). Daya tampung SMP tak sebanding lulusan SD. Medcom. https://www.medcom.id/pendidikan/news-pendidikan/gNQ0L3oK-daya-tampungsmp-tak-sebanding-lulusan-sd

Regulation of the Minister of Education and Culture regarding the Student Admission, Pub. L. No. 14 (2018). https://jdih.kemdikbud.go.id/arsip/Permendikbud_Tahun2018_Nomor 14.pdf

Nastiti, F. E., \& Abdu, A. R. N. (2020). Kajian: Kesiapan pendidikan Indonesia menghadapi era society 5.0. Edcomtech Jurnal Kajian Teknologi Pendidikan, 5(1), 61-66. https:/ / doi.org/ 10.17977/um039v5i12020p061

Nurdin, I., \& Hartati, S. (2019). Metodologi penelitian sosial. Media Sahabat Cendekia.

Nurlailiyah, A. (2019). Analisis kebijakan sistem zonasi terhadap perilaku siswa SMP di Yogyakarta. Realita: Jurnal Penelitian dan Kebudayaan Islam, 17(1), 13-21. https://doi.org/ 10.30762/realita.v17i1.1381

Nursanti, A. (2020). Surat keterangan domisili aspal di PPDB, Ganjar Pranowo: Gandeng polisi karena masuk pemalsuan data. Pikiran Rakyat. https://www.pikiran-rakyat.com/nasional/pr01575746/surat-keterangan-domisili-aspal-di-ppdb-ganjar-pranowo-gandeng-polisikarena-masuk-pemalsuan-data

Parker, L., \& Raihani, R. (2011). Democratizing Indonesia through education? Community participation in islamic schooling. Educational Management Administration \& Leadership, 39(6), 712-732. https://doi.org/10.1177/1741143211416389

Perdana, N. S. (2019). Implementasi PPDB zonasi dalam upaya pemerataan akses dan mutu pendidikan. Jurnal Pendidikan Glasser, 3(1), 78-92. https://doi.org/10.32529/glasser. v3i1.186

Salsabila, R. (2018). Penerapan metode Structured Dyadic Method (SDM) untuk meningkatkan aktivitas dan hasil belajar siswa SMK Nadatbul Ulama Buluwalang Kabupaten Malang [Unpublished bachelor's thesis]. Universitas Negeri Malang.

Sanjiwani, I. A. E. (2012). Analisis biaya pendidikan dan dampaknya terhadap kualitas proses pembelajaran dan aspirasi pendidikan siswa (Studi tentang persepsi para siswa SMA Dwijendra Denpasar tahun pelajaran 2011/2012). Jurnal Administrasi Pendidikan UNDIKSHA, 3(2). https://doi.org/10.23887/japi.v3i2.459

Sayidani, A., Gunawan, W. S., Muhammad, I., \& Fuady, J. (2016). Perbandingan prestasi belajar mahasiswa lulusan SMA dan SMK pada prodi S1 Pendidikan Teknik Informatika Universitas Negeri Malang. Teknologi Dan Kejuruan: Jurnal Teknologi, Kejuruan Dan Pengajarannya, 39(2), 155-162. http://dx.doi.org/10.17977/tk.v39i2.7789

Subagyo, P. (2009). Forecasting: Konsep dan aplikeasi (2nd ed.). BPFE-UGM.

Surani, A. (2012). Pengarub dukungan akademik orang tua dan jarak tempat tinggal terhadap prestasi belajar siswa pada mata pelajaran IPS kelas VII di SMP Negeri 8 Salatiga. Universitas Kristen Satya Wacana. 
176 - Gayuh Nugroho Dwi Putranto, Juliadi Nugroho, Muhammad Zid, \& Cahyadi Setiawan

doi doi:https://doi.org/10.21831/pep.v24i2.33026

Thaib, E. N. (2013). Hubungan antara prestasi belajar dengan kecerdasan emosional. Jurnal Ilmiah Didaktika, 13(2), 384-399. https://doi.org/10.22373/jid.v13i2.485

United Nation. (2005). Universal declaration of buman right. UNESDOC. http://portal.unesco. org/en/ev.php-URL_ID=31058\&URL_DO=DO_TOPIC\&URL_SECTION=201. html

Wahyuni, D. (2019). Permasalahan dan upaya perbaikan sistem zonasi dalam penerimaan peserta didik baru 2019. Info Singkat, Article 13. http://puslit.dpr.go.id

Windarto, R. (2013). Minat siswa SMP Negeri melanjtukan ke SMK ditinjau dari sosial ekonomi keluarga di Kabupaten Bantul. Jurnal Pendidikan Vokasi, 3(1), 103-116. https://doi.org/10.21831/jpv.v3i1.1585 